\title{
METHOD OF CALCULATION OF HEAT GENERATION \\ RATES FOR DWPF GLASS (U)
}

WSRC-RD--92-002-Rev. 2

by

M. J. Plodinec

DE93 012794

Savannah River Site

Aiken, South Carolina 29808

This paper was prepared in connection with work done under the above contract number with the U.S.

Department of Energy. By acceptance of this paper, the publisher and/or recipient acknowledges the U.S. Government's right to retain a nonexclusive, royalty-free license in and to any copyright covering this paper, along with the right to reproduce and to authorize others to reproduce all or part of the copyrighted paper. 


\section{DISCLAIMER}

This report was prepared as an account of work sponsored by an agency of the United States Government. Neither the United States Government nor any agency thereof, nor any of their employees, makes any warranty, express or implied, or assumes any legal liability or responsibility for the accuracy, completeness, or usefulness of any information, apparatus, product, or process disclosed, or represents that its use would not infringe privately owned rights. Reference herein to any specific commercial product, process, or service by trade name, trademark, manufacturer, or otherwise does not necessarily constitute or imply its endorsement, recommendation, or favoring by the United States Government or any agency thereof. The views and opinions of authors expressed herein do not necessarily state or reflect those of the United States Government or any agency thereof.

This report has been reproduced directly from the best available copy.

Available to DOE and DOE contractors from the Office of Scientific and Technical Information, P.O. Box 62, Oak Kidge, TN 37831; prices available from (615) 576-8401, FTS 626-8401.

Available to the public from the National Technical Information Service, U.S. Department of Commerce, 5285 Port Royal Rd., Springfield, VA 22161. 


\section{MFTHOD OF CAICUTATION OF FTAT GMNGRATION RATHS FOR DKPF GLASS}

\section{INTRODOCTION AND SUMMARY}

The Waste Acceptance Preliminary Specifications (WAPS) 1 require estimates of the heat generation rate of DWPF waste glasses. Estimates of the heat generation rates of projected glass compositions are to be reported in the Waste Form Qualification Report. Similar estimates for actual production glasses are to be reported in the Production Records. In this report, a method of calculating the heat generation rate from the radionuclide inventory is provided. Application of the method to the DWPF Design-Basis glass indicates that the heat generation rate can be accurately estimated from the Sr-90, Y-90, Cs-137, Ba-137m, and Pu-238 contents alone.

\section{SPFCIFICATION AND STRATMGY}

The WAPS specification for heat generation (Specification 3.7) requires that
"The producer shall document in the WQR the expected thermal output of canistered waste forms and the range of expected variation in thermal output for each waste type during the life of the production facility. The method to be used for demonstrating compliance shall be described by the producer in the WCP. Projections for compositions not available for reporting in the initial WQR shall be included in an addendum to the WQR.
The producer shall report in the Production Records the heat generation rate for each canistered waste form at time of production. The estimated error of the heat generation rates shall be provided in the WQR. The pro- ducer shall describe the plan for compliance in the WCP." 1

The DWPF will calculate the heat generation rate from the radionuclide inventory. ${ }^{2}$ In this report, up-to-date factors for converting curies to watts are listed. Calculations of the heat generation rate of the DWPE Design-Basis glass as a function of time are provided to demonstrate the use of the method.

\section{RADIONOCLIDES TO BF RFPORTHE}

The recommended factors to convert curies to watts are listed in Table 1. These values are from the repository program's Integrated Data Base, ${ }^{3}$ and are more current than the values used in the DWPE Basic Data Report. ${ }^{4}$ All of the radionuclides whose content will be reported to the repository in the Production Records are included in Table 1 . These radionuclides have a half-life $>10$ 
TABLE 1

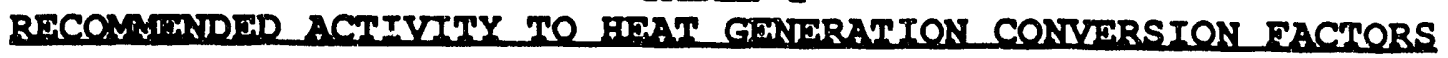

\begin{tabular}{|c|c|}
\hline Nuclide & Watts/Curi \\
\hline $\begin{array}{l}\text { Co-60 } \\
N i-59+ \\
N i-63 \\
\text { Se-79 } \\
\text { Sr-90 } \\
Y-90 \\
\mathrm{Zr}-93 \\
\mathrm{Nb}-93 \mathrm{~m} \\
\mathrm{Tc}-99 \\
\mathrm{Ru}-106 \\
\mathrm{R}-106 \\
\mathrm{Pd}-107 \\
\mathrm{Sn}-126 \\
\mathrm{Sb}-125 \\
\mathrm{Cs}-134 \\
\mathrm{Cs}-135 \\
\mathrm{Cs}-137 \\
\mathrm{Ba}-137 \mathrm{~m} \\
\mathrm{Ce}-144 \\
\mathrm{Pr}-144 \\
\mathrm{Pm}-147 \\
\mathrm{Sm}-151 \\
\mathrm{Eu}-154 \\
\mathrm{Eu}-155 \\
\mathrm{Th}-230 \\
\mathrm{~Np}-237 \\
\mathrm{D}-234 \\
\mathrm{D}-238 \\
\mathrm{Pu}-238 \\
\mathrm{Pu}-239 \\
\mathrm{Pu}-240 \\
\mathrm{Pu}-241 \\
\mathrm{Pu}-242 \\
\mathrm{Am}-241 \\
\mathrm{Am}-243 \\
\mathrm{Cm}-244\end{array}$ & $\begin{array}{l}1.54 \mathrm{E}-02 \star \\
3.98 \mathrm{E}-05 \\
1.01 \mathrm{E}-04 \\
3.13 \mathrm{E}-04 \\
1.16 \mathrm{E}-03 \\
5.54 \mathrm{E}-03 \\
2.90 \mathrm{E}-04 \\
1.77 \mathrm{E}-04 \\
5.00 \mathrm{E}-04 \\
5.95 \mathrm{E}-04 \\
9.60 \mathrm{E}-03 \\
5.50 \mathrm{E}-05 \\
1.08 \mathrm{E}-03 \\
3.37 \mathrm{E}-03 \\
1.02 \mathrm{E}-02 \\
3.30 \mathrm{E}-04 \\
1.11 \mathrm{E}-03 \\
3.94 \mathrm{E}-03 \\
6.58 \mathrm{E}-04 \\
7.34 \mathrm{E}-03 \\
3.70 \mathrm{E}-04 \\
7.41 \mathrm{E}-04 \\
9.08 \mathrm{E}-03 \\
7.59 \mathrm{E}-04 \\
2.77 \mathrm{E}-02 \\
2.88 \mathrm{E}-02 \\
2.83 \mathrm{E}-02 \\
2.49 \mathrm{E}-02 \\
3.26 \mathrm{E}-02 \\
3.02 \mathrm{E}-02 \\
3.06 \mathrm{E}-02 \\
3.10 \mathrm{E}-05 \\
2.90 \mathrm{E}-02 \\
3.28 \mathrm{E}-02 \\
3.15 \mathrm{E}-02 \\
3.44 \mathrm{E}-02\end{array}$ \\
\hline
\end{tabular}

$\star 1.54 \mathrm{E}-02=1.54 \cdot 10^{-2}$.

tRadionuclides printed in bold are ones to be reported in the Production Records. 


\section{TABIE 2}

RADIONDCIIDF CONHANT OF DFSIGN-BASTS GTASS AS A FUNCTION OF TIMT (Units are curies/canister, 0 years = time of production of glass)

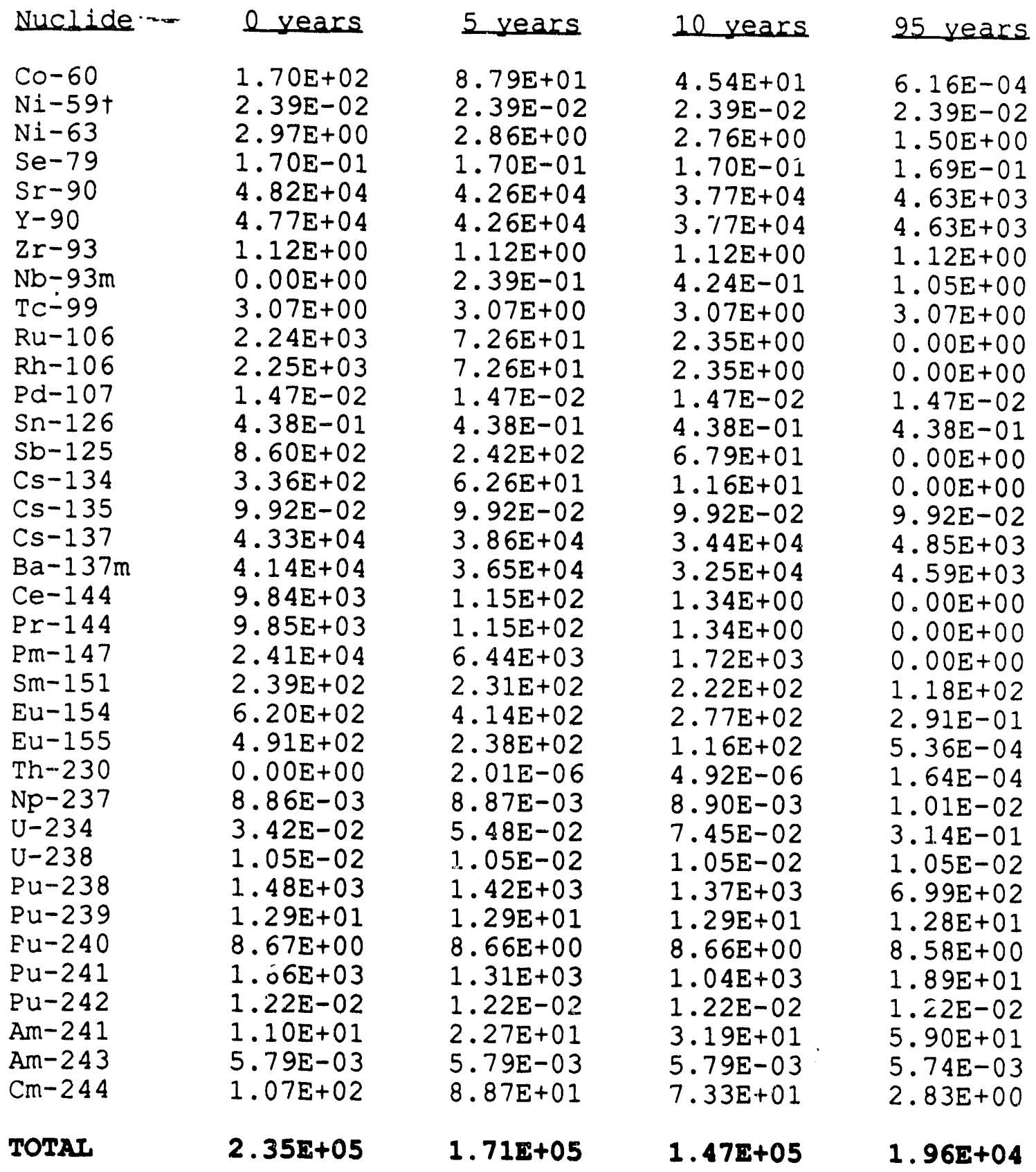


TABLE 3

HFAT GHNFRATTON BY DFSIGN-BASIS GIASS AS A FUNCTION OF TINT

(Units are watts/canister, 0 years = time of production of glass)

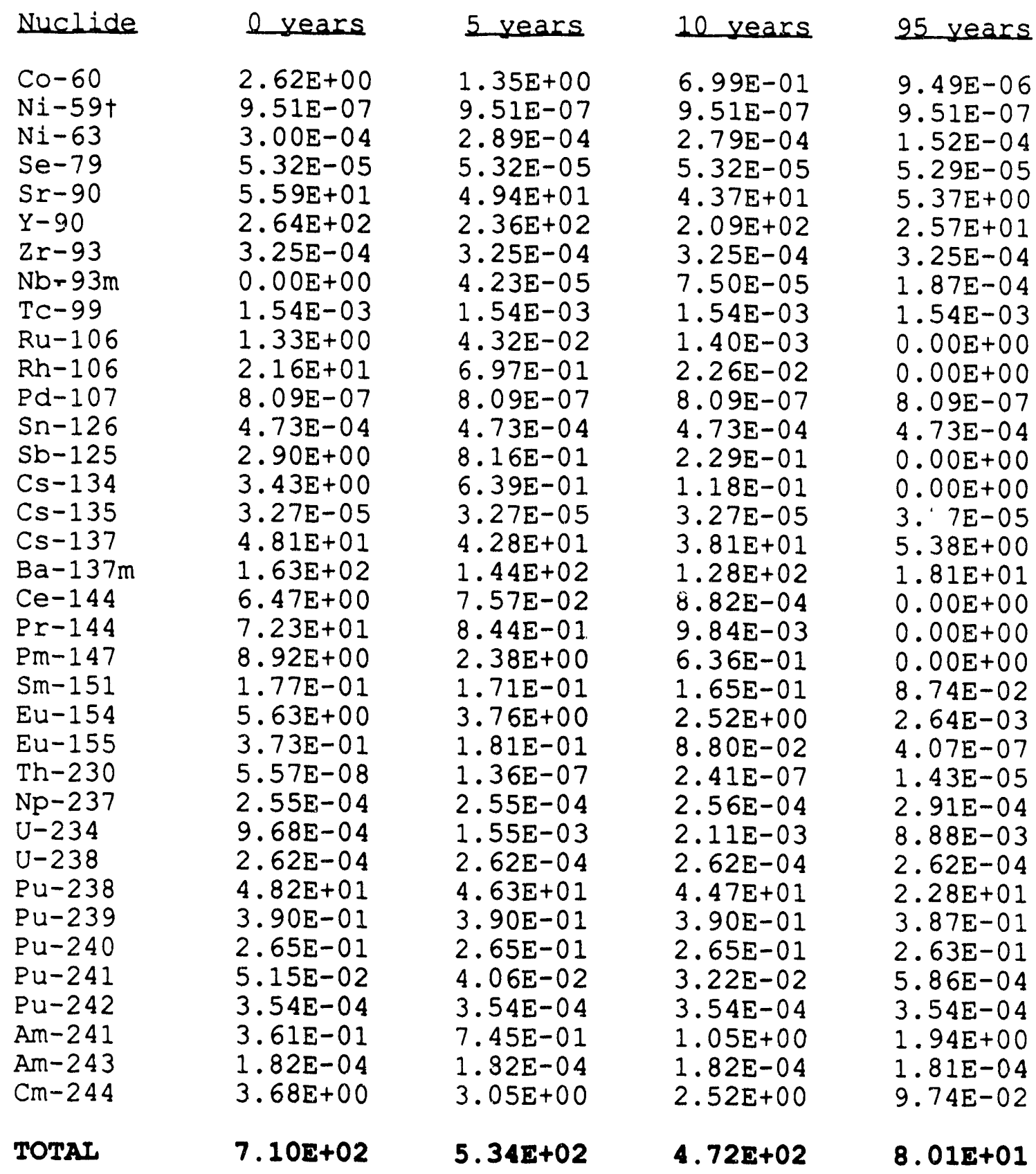


years, and constitute at least 0.01 \& (on a curie basis) of the radionuclide inventory of the Design-Basis glass at the time of production, or at some later time up to 1100 years after production. 5 Also included in the Table are shorter-lived radionuclides which are present in large enough quantities to contribute significantly to the heat generation rate at time of production, in watts.

\section{CALCUTATION MIFAOD AND SAMPIT APPIICATION}

The calculation is an extremely simple, albeit tedious, one. the content of each radionuclide in curies is multiplied by the =ppropriate factor in Table 1, and the resulting values summed to give the heat generation rate of the glass of interest.

As examples of the application of the method, Table 2 contains the radionuclide content of the Design-Basis glass at various times after production. Application of the method described here results in the values in Table 3. These values are higher than those in the Basic Data Report by approximately $3 \%$. Use of the more current conversion factors in this report is recommended.

Based on the values in Table 3 , the heat generation rate is dominated by just five species within 10 years after production. The contributions from Cs-137, Ba-137m, Sr-90, Y-90, and Pu-238 account for approximately 97 of the heat generation rate from 5 years after production until approximately 100 years after production. Since the curie contents of these five species can be relatively easily determined, they provide a quick method of determining the heat generation rate of DWPE glass. Although exclusion of other species introduces a slight negative bias in the calculated values, the resulting inaccuracy is negligible.

\section{RTHERTACPS}

1. Office of Civilian Radioactive Waste Management, Waste Acceptance Preliminary Specifications for Vitrified High-Level Waste Forms, Draft for approval, June, 1991.

2. Defense Waste Processing Facility, DWPF Waste Form Compliance Plan, WSRC SW4-6, Revision 0, March, 1990.

3. Oak Ridge National Laboratory, Integrated Data Base for 1991: U. S. Spent Fuel and Radioactive Waste Inventories, Projections, and Characteristics, Revision 7, USDOE Report RW-0006, Washington, DC (1991).

4. Defense Waste Processing Facility, Basic Data Report, Revision 139, WSRC-RP-92-1186 (1992).

5. B. A. Hacker, "Radionuclides to be Reported for DWPF Waste Acceptance," DPST-86-789, November 19, 1986. 

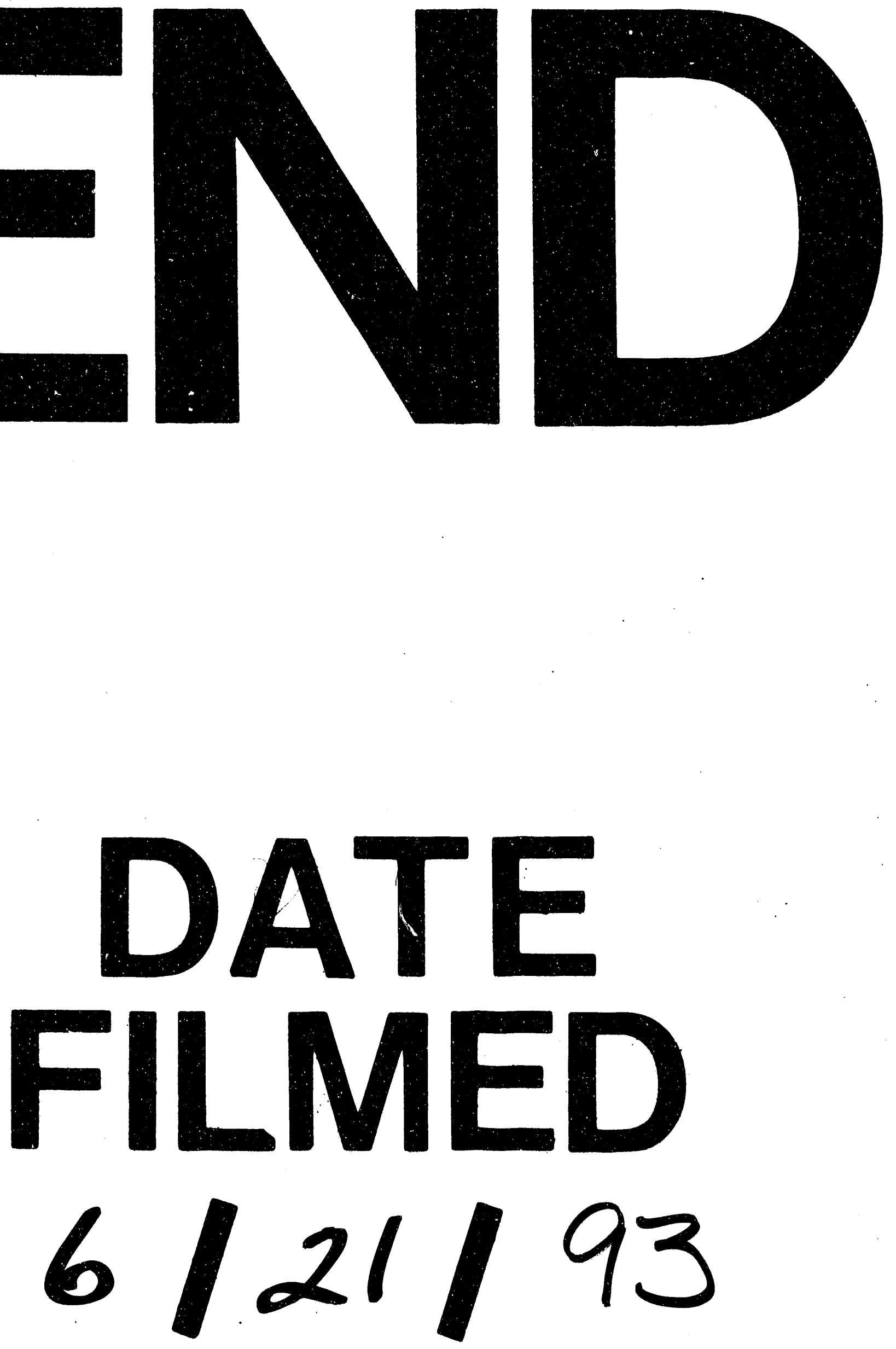
